\title{
Addison's Disease Presenting With Idiopathic Intracranial Hypertension in a Young Female
}

\author{
Abigail K. Fowlie ${ }^{1}$, Muhammad S. Majeed ${ }^{1}$, Eleni Karathanasi ${ }^{1}$ \\ 1. Endocrinology and Diabetes, Western Sussex Hospitals National Health Service Foundation Trust, Worthing, GBR
}

Corresponding author: Abigail K. Fowlie, abigail.fowlie@nhs.net

\begin{abstract}
Addison's disease presenting with idiopathic intracranial hypertension (IIH) is rare but well reported in the literature. IIH has also been reported to occur with other endocrine conditions. We explore some interesting diagnostic and management challenges of a young female that presented with IIH and Addison's disease. We discuss the features of this unifying neuroendocrine diagnosis.
\end{abstract}

A previously well 17-year-old female presented to the Emergency Department after a syncopal episode. She had been suffering from worsening and increasing headaches over the last eight months, with vomiting once or twice per day. She had papilledema and reduced visual fields bilaterally. CT head and venogram were normal. Lumbar puncture (LP) opening pressure was raised. She was noted to be hypotensive and hyponatremic. Investigations for hyponatremia revealed random cortisol of $<28 \mathrm{nmol} / \mathrm{L}$. She was treated for adrenal crisis. Further investigations were performed and she was diagnosed with IIH associated with Addison's disease.

Addison's disease should always be considered in a patient presenting with IIH and hyponatremia. While the mechanism for this association is not completely clear, treating the underlying adrenal insufficiency with steroid replacement alone is an effective treatment and provides symptomatic relief.

Review began 05/13/2021 Review ended 05/18/2021 Published 05/23/2021

\section{(c) Copyright 2021}

Fowlie et al. This is an open access article distributed under the terms of the Creative Commons Attribution License CC-BY 4.0., which permits unrestricted use, distribution, and reproduction in any medium, provided the original author and source are credited.
Categories: Endocrinology/Diabetes/Metabolism, Neurology, Pediatrics

Keywords: addison's disease, idiopathic intracranial hypertension (iih), headache disorders, primary adrenal insufficiency, hyponatremia

\section{Introduction}

A definitive diagnosis of idiopathic intracranial hypertension (IIH) can be made on the basis of raised intracranial pressure and papilledema with normal neuroimaging, cerebrospinal fluid (CSF) composition, and neurological examination (except for cranial nerve abnormalities) [1].

The nomenclature to describe this condition is inconsistent in the literature. Benign IIH has long been discredited due to the potential for irreversible visual impairment. IIH is a diagnosis of exclusion, appropriate for a subset of patients who satisfy the above criteria with no clear secondary cause [1]. There is a significant proportion of patients whereby an underlying etiology for the syndrome is identified. These patients respond to etiology-specific treatments.

IIH has been associated with several endocrine conditions including hyperthyroidism [2], exogenous growth hormone [3], treatment of Cushing's disease [4,5], secondary adrenal insufficiency [6], and Addison's disease [7-11]. There have been only seven reported cases of Addison's disease presenting as IIH, six of which were children [7-11] and one an adult [12].

\section{Case Presentation}

Our patient was first seen in the pediatric clinic with a six-month history of frontal headaches. The headaches were occurring every day and were worse in the morning. She reported intermittent visual blurring and morning emesis. Systems examination was normal and funduscopic examination of nondilated pupils was reported normal. Baseline blood tests were within the normal range. Family history was remarkable for migraines. Sumatriptan was commenced with no effect.

Two months later, she presented with worsening headaches and following a syncopal episode. The headaches were now associated with vomiting multiple times a day. She described a 'fog' over her eyes with intermittent double vision and bilateral tinnitus. She reported some recent weight loss and felt light-headed on standing. She had no other systemic symptoms, there were no growth concerns and she had a regular menstrual cycle. There was no past medical history. She was on no medication or contraceptive pill at the time of admission.

On examination, she appeared slim with a BMI of $20 \mathrm{~kg} / \mathrm{m} 2$. She had blood pressure (BP) of 89/48 mmHg 


\section{Cureus}

and a pulse of 91 beats per minute. The fundal examination was remarkable for bilateral disc swelling (Figure 1), which was further confirmed on optical coherence tomography scanning. Humphrey visual field testing showed reduced visual fields, on the right more so than the left. Neurological examination was otherwise normal.
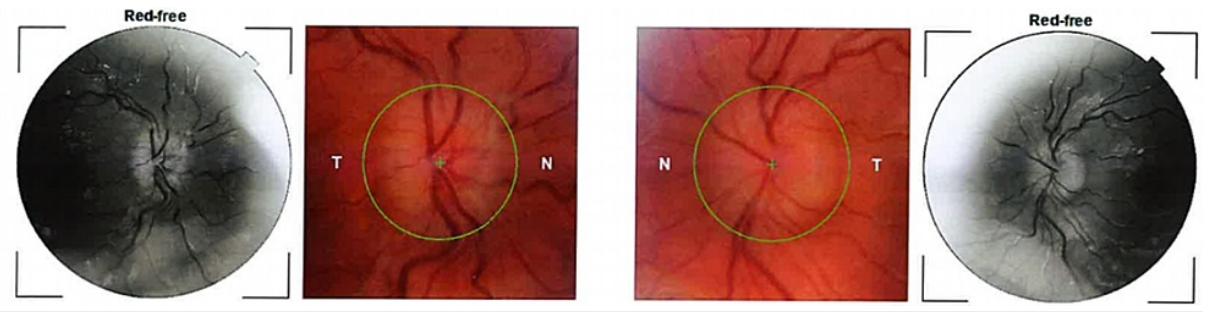

FIGURE 1: Retinal photographs of our patient showing papilledema.

Laboratory blood tests disclosed isolated hyponatremia of $126 \mathrm{mmol} / \mathrm{L}$. CT head and CT venogram showed no abnormalities. Lumbar puncture (LP) performed in the lateral decubitus position revealed raised opening pressure of $36 \mathrm{~cm} \mathrm{H20}$, reduced to a closing pressure of $12 \mathrm{~cm} \mathrm{H} 20$ after therapeutic drainage. CSF had a normal composition and was sterile.

Following LP, her headaches improved and she was commenced on acetazolamide $250 \mathrm{mg}$ twice daily for presumed IIH. However, just one day later the vomiting returned and the clinical picture appeared unchanged. Subsequent MRI disclosed no abnormalities. Repeat blood tests showed persistent hyponatremia, which prompted further investigations.

Random serum cortisol was measured and found to be extremely low $(<28 \mathrm{nmol} / \mathrm{l})$. She was commenced on intravenous hydrocortisone and $0.9 \%$ saline infusion. It was at this point that the diffuse hyperpigmentation of her skin (incongruent to her mother's complexion) was recognized (Figure 2). This had not been documented previously and we suspect this was because she was always examined in a darkened room. On discussion with the patient and her mother, they assumed she had retained her "tan" well since their summer holiday last year.

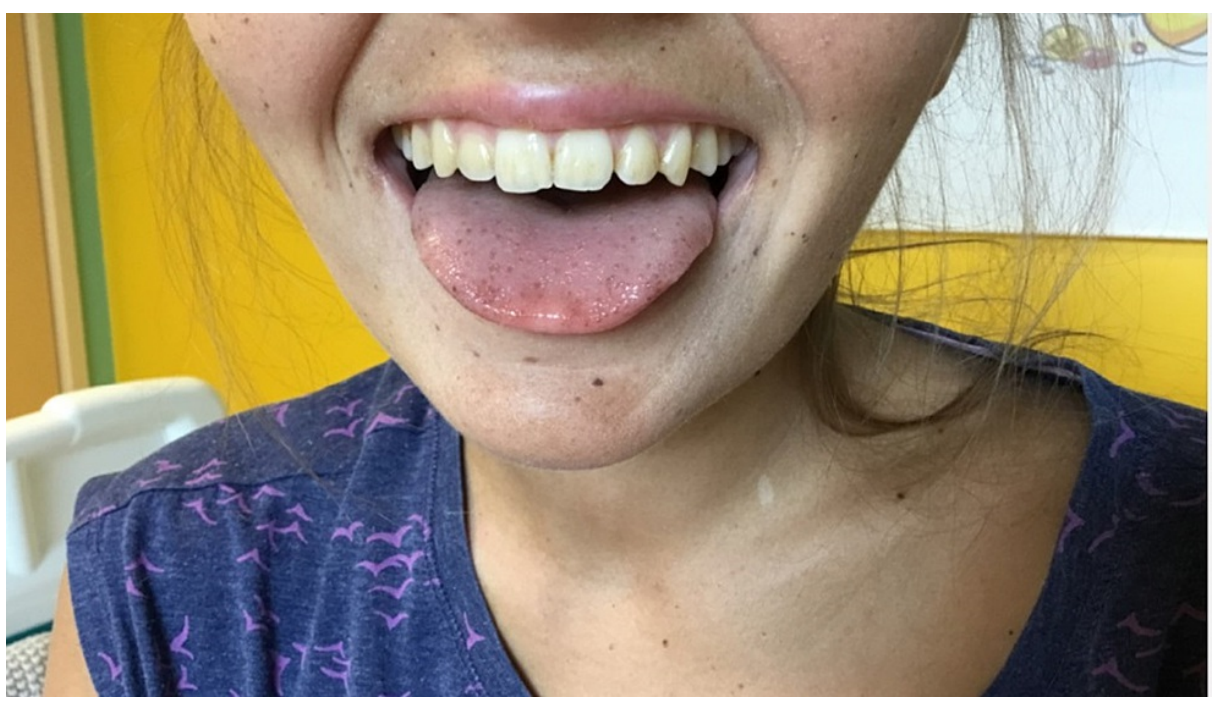

FIGURE 2: A picture showing the pigmentation of our patient's skin and tongue.

A comprehensive set of endocrine and autoimmune laboratory blood tests was performed (Table 1). Abnormal results included low serum aldosterone $(68 \mathrm{pmol} / \mathrm{L})$ and increased plasma renin activity ( 894 $\mathrm{mu} / \mathrm{L}$ ). Unexpectedly, morning plasma adrenocorticotropic hormone (ACTH) was low at $9 \mathrm{ng} / \mathrm{L}$. She underwent adrenal stimulation with a $250 \mathrm{mcg}$ short synacthen test. Basal cortisol level was $17 \mathrm{nmol} / \mathrm{L}$. Subsequent serum cortisol concentrations were $17 \mathrm{nmol} / \mathrm{L}$ and $20 \mathrm{nmol} / \mathrm{L}$ at 30 and 60 minutes, respectively. High titre adrenal antibodies were detected. Despite the initial low plasma ACTH, the clinical and biochemical picture confirmed Addison's disease in this patient. The hyponatremia corrected with corticosteroid replacement. Repeat ACTH level at a later date revealed a high ACTH level of $3259 \mathrm{ng} / \mathrm{L}$. 


\section{Cureus}

\begin{tabular}{|c|c|}
\hline Blood test & Result \\
\hline Sodium & $126 \mathrm{mmol} / \mathrm{L}$ \\
\hline Potassium & $4.3 \mathrm{mmol} / \mathrm{L}$ \\
\hline Urea & $5.6 \mathrm{mmol} / \mathrm{L}$ \\
\hline Creatinine & 55 ц $\mathrm{mol} / \mathrm{L}$ \\
\hline Estimated Glomerular Filtration Rate & $>90 \mathrm{ml} / \mathrm{min}$ \\
\hline Serum Osmolality & $273 \mathrm{mmol} / \mathrm{kg}$ \\
\hline Urine Osmolality & $254 \mathrm{nmol} / \mathrm{L}$ \\
\hline Urine Sodium & $24 \mathrm{nmol} / \mathrm{kg}$ \\
\hline Adrenocorticotropic Hormone (ACTH) & Initially $9 \mathrm{ng} / \mathrm{L}$, later $3259 \mathrm{ng} / \mathrm{L}$ \\
\hline Aldosterone & $68 \mathrm{pmol} / \mathrm{L}$ \\
\hline Renin & $894.3 \mathrm{mu} / \mathrm{L}$ \\
\hline Aldosterone:Renin Ratio & 0 \\
\hline Adrenal Antibodies & Positive \\
\hline Baseline Cortisol & $1 / \mathrm{nmol} / \mathrm{L}$ \\
\hline Cortisol 30 Mins After Tetracosactide & $17 \mathrm{nmol} / \mathrm{L}$ \\
\hline Cortisol 60 Mins After Tetracosactide & $20 \mathrm{nmol} / \mathrm{L}$ \\
\hline Thyroid-Stimulating Hormone & $0.56 \mathrm{mu} / \mathrm{L}$ \\
\hline Thyroxine (T4) & $13.5 \mathrm{pmol} / \mathrm{L}$ \\
\hline I hyrold Peroxidase Antibodies & $2.2 \mathrm{lu} / \mathrm{L}$ \\
\hline Insulin-like Growth Factor-1 & $32.9 \mathrm{nmol} / \mathrm{L}$ \\
\hline Prolactin & $468 \mathrm{mu} / \mathrm{L}$ \\
\hline Luteinizing Hormone & $4.1 \mathrm{iu} / \mathrm{L}$ \\
\hline Oestradiol & $308 \mathrm{pmol} / \mathrm{L}$ \\
\hline IgA Tissue Transglutaminase Antibodies & $0.3 \mathrm{U} / \mathrm{ml}$ \\
\hline Liver Kidney Microsomal Antibodies & Negative \\
\hline Smooth Muscle Antibodies & Negative \\
\hline Mitochondrial Antibodies & Negative \\
\hline Gastric Parietal Cell Antibodies & Negative \\
\hline Anti-Nuclear Antibodies & Negative \\
\hline Intrinsic Factor & $<0.5 \mathrm{u} / \mathrm{mL}$ \\
\hline
\end{tabular}

TABLE 1: Table displaying the results of blood tests performed.

She was discharged on acetazolamide, hydrocortisone, and fludrocortisone. She was reviewed over the proceeding months with difficulty tapering the dose of hydrocortisone, due to persisting tiredness and occasional vomiting even on higher doses of hydrocortisone. On one occasion her sodium was also noted to be low at $130 \mathrm{mmol} / \mathrm{L}$ despite high doses of oral hydrocortisone. Acetazolamide was discontinued and her symptoms improved with no regression in her ophthalmology examination.

\section{Discussion}

The mechanisms for the association between IIH and Addison's disease are not certain. It has been 
postulated that IIH arises from an increase in CSF volume secondary to delayed CSF absorption [13]. Experimental studies have shown delayed CSF absorption, without ventricular dilatation due to increased resistance of flow across absorptive channels following acute steroid withdrawal [13]. The putative effects of acute corticosteroid withdrawal on CSF secretion, implicate the enzyme $11 \beta$-hydroxysteroid dehydrogenase type 1 , an enzyme highly expressed in choroid plexus epithelium that converts inactive cortisone to active cortisol [14]. Cortisol can activate the mineralocorticoid receptors in the choroid plexus with similar affinity to aldosterone, leading to active sodium secretion by the $\mathrm{Na} / \mathrm{K}$ ATPase at the choroid plexus membrane, movement of sodium ions into the cerebral ventricle, and an osmotic gradient to drive CSF secretion [14].

Our case signifies diagnostic and management challenges to clinicians. Both Addison's disease and IIH presented at the same time with an initial focus on a presumed diagnosis of IIH. Serum sodium which was low on admission was missed initially and later baseline workup for hyponatremia revealed extremely low cortisol levels. Raised renin levels with low aldosterone supported the diagnosis of primary adrenal insufficiency, however, ACTH levels were falsely low with no clear explanation. ACTH analysis was done by Siemens IMMULITE assay and the initial low level was related to possible mishandling/degradation or spurious analysis.

In the proceeding months after discharge, we postulated that there was impaired absorption of hydrocortisone due to difficulty in tapering the dose. The malabsorption screen was negative and adjusting the timing of her medication had no effect. In the British National Formulary (BNF) [15], acetazolamide and hydrocortisone are not recorded to interact. However, in this case, we have had difficulty managing adrenal insufficiency with the concomitant use of acetazolamide. This may be because some of the uncommon documented side effects of acetazolamide mimic those of adrenal insufficiency; namely vomiting and tiredness [15]. On discontinuation of acetazolamide, she was able to reduce the dose of hydrocortisone and was discharged from ophthalmology follow-up. Comparing other case reports, the majority of IIH associated with Addison's disease responded well to steroid replacement alone, and only two authors combined this for a short period with acetazolamide $[8,12]$.

\section{Conclusions}

This case highlights the importance of identifying secondary causes in patients that present with IIH. While IIH is an unusual presentation of the Addisonian crisis, the clinician should be aware of this association, and Addison's disease should always be considered when hyponatremia co-exists with IIH. Although acetazolamide is the standard treatment for IIH alone, early steroid replacement in Addison's associated with IIH controls symptoms and may reduce the risk of visual loss.

\section{Additional Information \\ Disclosures}

Human subjects: Consent was obtained or waived by all participants in this study. Conflicts of interest: In compliance with the ICMJE uniform disclosure form, all authors declare the following: Payment/services info: All authors have declared that no financial support was received from any organization for the submitted work. Financial relationships: All authors have declared that they have no financial relationships at present or within the previous three years with any organizations that might have an interest in the submitted work. Other relationships: All authors have declared that there are no other relationships or activities that could appear to have influenced the submitted work.

\section{References}

1. Friedman DI, Liu GT, Digre KB: Revised diagnostic criteria for the pseudotumor cerebri syndrome in adults and children. Neurology. 2013, 81:1159-1165. 10.1212/WNL.0b013e3182a55f17

2. Dickman MS, Somasundaram M, Brzozowski L: Pseudotumor cerebri and hyperthyroidism. N Y State J Med. 1980, 80:1118-1120

3. Malozowski S, Tanner LA, Wysowski DK, Fleming GA, Stadel BV: Benign intracranial hypertension in children with growth hormone deficiency treated with growth hormone. J Pediatr. 1995, 126:996-999. 10.1016/S0022-3476(95)70232-6

4. Newman PK, Snow M, Hudgson P: Benign intracranial hypertension and Cushing's disease. Br Med J. 1980, 281:113. 10.1136/bmj.281.6233.113

5. Zada G, Tirosh A, Kaiser UB, Laws ER, Woodmansee WW: Cushing's disease and idiopathic intracrania hypertension: case report and review of underlying pathophysiological mechanisms. J Clin Endocrinol Metab. 2010, 95:4850-4854. 10.1210/jc.2010-0896

6. Shenouda S, Al-Farawi K, Dolan J, Flesher SL: Idiopathic intracranial hypertension as a presenting sign of adrenal insufficiency. SAGE Open Med Case Rep. 2018, 6:2050313X17753787. 10.1177/2050313X17753787

7. Alexandrakis G, Filatov V, Walsh T: Pseudotumor cerebri in a 12-year-old boy with Addison's disease . Am J Ophthalmol. 1993, 116:650-651. 10.1016/S0002-9394(14)73215-5

8. Condulis N, Germain G, Charest N, Levy S, Carpenter TO: Pseudotumor cerebri: a presenting manifestation of Addison's disease. Clin Pediatr. 1997, 36:711-713. 10.1177/000992289703601208

9. Geenen C, Tein I, Ehrlich RM: Addison's disease presenting with cerebral edema . Can J Neurol Sci. 1996, 23:141-144. 10.1017/s0317167100038889

10. Kumar P, Raja R, Chauhan V, Rai M, Sunder S: Pseudotumor cerebri as a manifestation of Addison's disease . 


\section{Cureus}

Int J Endocrinol. 2006, 3:1-3.

11. Leggio MG, Cappa A, Molinari M, Corsello SM, Gainotti G: Pseudotumor cerebri as presenting syndrome of Addisonian crisis. Ital J Neurol Sci. 1995, 16:387-389. 10.1007/BF02229174

12. Sharma D, Mukherjee R, Moore P, Cuthbertson DJ: Addison's disease presenting with idiopathic intracranial hypertension in 24-year-old woman: a case report. J Med Case Rep. 2010, 4:60. 10.1186/1752-1947-4-60

13. Johnston I, Paterson A: Benign intracranial hypertension: I. Diagnosis and prognosis. Brain. 1974, 97:289300. 10.1093/brain/97.2.289

14. Salpietro V, Polizzi A, Bertè LF, et al.: Idiopathic intracranial hypertension: a unifying neuroendocrine hypothesis through the adrenal-brain axis. Neuro Endocrinol Lett. 2012, 33:569-573.

15. Joint Formulary Committee: British National Formulary. BMJ Publishing Group and Pharmaceutical Press, London; 2020. 